\title{
Physiological potential of seeds and morphological characterization of Campomanesia adamantium seedlings
}

\author{
Érica Fernandes Leão-Araújo ${ }^{1}$, Eli Regina Barboza de Souza ${ }^{2}$, \\ Nei Peixoto ${ }^{3}$, Francisco Guilhien Gomes-Júnior ${ }^{4}$
}

\begin{abstract}
The cultivation of native fruit species depends on the existence of consistent technical and scientific information on the germination and vigor of seeds for efficient management by seedling producers. The evaluation of the physiological potential of seeds is performed through germination and vigor tests, which must be standardized to ensure the generation of accurate information. For Campomanesia adamantium, information on parameters for conducting physiological tests is scarce. The aims of this work were (i) to evaluate the effect of temperature and seed positioning on the substrate for seed germination and vigor, and (ii) to characterize and describe the essential structures and main types of seedling abnormality. After harvest, fruits were pulped and, after seed extraction, germination tests were carried out for 42 days at three temperatures $\left(20,25\right.$ and $30{ }^{\circ} \mathrm{C}$ ), with seeds positioned in the germination substrate in two ways (between paper and on paper). Seed vigor was evaluated by means of the first germination count (performed on the 20th day) and the germination rate index. The temperature and substrate interaction did not influence variables under study. The position of seeds on the substrate did not influence the physiological potential results. No differences were observed between seed germination temperatures; however, seeds submitted to germination at $25^{\circ} \mathrm{C}$ showed higher vigor compared to the other temperatures. Germination and vigor tests, based on seedling performance, should be performed at constant temperature of $25^{\circ} \mathrm{C}$ and seed positioning between paper and on paper may be used. Germination in C. adamantium was characterized as epigeal. Index terms: abnormal seedling, gabiroba, temperature, viability, vigor.
\end{abstract}

\section{Potencial fisiológico de sementes e caracterização morfológica de plântulas de Campomanesia adamantium}

Corresponding author: erica.leao@ifgoiano.edu.br

Received: January 15,2019 Accepted: April 25, 2019

Copyright: All the contents of this journal, except where otherwise noted, is licensed under a Creative Commons Attribution License.

\section{(cc) $\mathbf{E Y}$}

Resumo- O cultivo de espécies frutíferas nativas depende da existência de informações técnicas e científicas consistentes sobre a germinação e o vigor das sementes para o eficiente manejo pelos produtores de mudas. A avaliação do potencial fisiológico de sementes é realizada por meio de testes de germinação e vigor, os quais devem ser padronizados para garantir a geração de informações precisas. Para Campomanesia adamantium, são raras as informações sobre os parâmetros para realização de testes fisiológicos. Assim, este trabalho foi realizado com os objetivos de; (i) avaliar o efeito da temperatura e do posicionamento das sementes no substrato para germinação e vigor das sementes e (ii) caracterizar e descrever as estruturas essenciais e os principais tipos de anormalidade em plântulas dessa espécie. Após a coleta, os frutos foram despolpados e, após a extração das sementes, realizados testes de germinação durante 42 dias, em três temperaturas $\left(20 ; 25\right.$ e $\left.30^{\circ} \mathrm{C}\right)$, com as sementes posicionadas no substrato de germinação de duas maneiras (entre papel e sobre papel). A avaliação do vigor das sementes foi realizada por meio da primeira contagem de germinação (realizada no $20^{\circ}$ dia) e do índice de velocidade de germinação. A interação temperatura e substrato não influenciou nas variáveis estudadas. $\mathrm{O}$ tipo de posicionamento das sementes no substrato também não influenciou nos resultados do potencial fisiológico. Não foram observadas diferenças entre as temperaturas na germinação das sementes, porém sementes submetidas à germinação $\mathrm{a}^{\circ} \mathrm{C}$, apresentam vigor superior às demais temperaturas. Os testes de germinação e vigor, baseados no desempenho das plântulas, devem ser realizados na temperatura constante de $25^{\circ} \mathrm{C}$, e pode ser utilizado o posicionamento das sementes entre papel ou sobre papel. A germinação em C. adamantium foi caracterizada como epígea.

Termos para Indexação: plântula anormal, gabiroba, temperatura, viabilidade, vigor. 
Brazil is a country with rich vegetal biodiversity, and native fruit species represent the genetic richness, revealed by the high potential of use of these species. Campomanesia adamantium (Cambess.) O. Berg. is a fruit of the family Myrtaceae and native to the Brazilian Cerrado (LANDRUM, 1986). Fruits are consumed fresh and used in the manufacture of juices, sweets and ice cream (ARAÚJO and SOUZA, 2018). In addition, the plant has high medicinal potential (LORENZI et al., 2006) and can also be used in the alcoholic distillate industry (VALLILO et al., 2006), being also an ally of human health due to its antioxidant activity (COUTINHO et al., 2008). Despite potentialities, its use is restricted to extractivism, and technical and scientific information on the species is fundamental for the establishment of commercial crops. Aspects related to plant multiplication are the basis for enabling large-scale cultivation (ARAÚJO and SOUZA, 2018).

For $C$. adamantium, the most common form of multiplication is via the sexed route (DONADIO et al., 2004). Seeds with high physiological potential, free of pathogens and mechanical injuries guarantee normal embryo development and the formation of high-vigor seedlings. The evaluation of the physiological potential of seeds is commonly performed through germination and vigor tests (PESKE et al., 2013).

The germination test is described in the Rules for Seed Analysis - RAS (BRASIL, 2009) for a large number of species, indicating information such as evaluation dates, substrates to be used and exposure temperature during the test. These recommendations should be followed to obtain maximum germination potential of the seed lot. However, species such as $C$. adamantium, which are not listed in RAS, still require studies aimed at establishing safe germination parameters. Once these parameters have been defined, vigor tests, such as those based on seedling performance, can also be performed, since many of them are performed in combination with the germination test, such as the germination first count and the speed germination index (NAKAGAWA, 1999). Thus, there is a lack of data regarding the standardization of germination and vigor tests, especially for native Brazilian fruit species, and therefore, studies are needed to determine optimal conditions for these evaluations.

The results of germination and vigor tests can be influenced, among other factors, by temperature and positioning of seeds on the substrate used for germination. The substrate is the physical support on which seeds are placed and has the important function of maintaining the proper conditions for germination and development of seedlings. Therefore, choosing the correct positioning of seeds on the substrate is important to adapt seed requirements in relation to its size and shape, since there may be variations among species (BRASIL, 2009). Temperature affects germination rate, percentage and uniformity, and optimum temperature is that that allows maximum germination in the shortest period of time (MARCOS-FILHO, 2015).

The germination test aims to determine the maximum emergence potential of normal seedlings in a seed lot (BRASIL, 2009). The Brazilian rules for seed analysis (BRASIL, 2009) and the international rule (ISTA, 2018) define that seed germination is the emergence and development of essential embryo structures, which reveals the potential to produce a normal seedling under favorable conditions. These rules describe, in general, the criteria that should be used. However, variations in size and presence of structures among species may make the use of these criteria difficult. Thus, it is important to know the structures of the species to be evaluated. In addition, for the correct identification of the physiological potential of seeds, it is necessary to know the seedling structures.

The aims of this work were (i) to evaluate the effect of temperature and seed positioning on the substrate for seed germination and vigor, and (ii) to characterize and describe the essential structures and main types of abnormality in C. adamantium seedlings.

C. adamantium fruits were collected between October and December 2017, from 360 previously identified matrices. Plants were approximately 14 years old and their coordinates are $17^{\circ} 43^{\prime} 19^{\prime \prime} \mathrm{S}, 48^{\circ} 09^{\prime} 35^{\prime \prime} \mathrm{W}$ and altitude of $820 \mathrm{~m}$ a.s.1. On the occasion of the anthesis, flowers were marked and fruits were collected 50 to 65 days after floral opening. Pulping was manually performed and pulp together with seeds was placed for fermentation in $25 \%$ ammonium hydroxide solution for 48 hours. Seeds were then washed in running water for five minutes and placed on germinating paper under shade and laboratory conditions in a single layer to dry superficially for 30 minutes.

To evaluate the effect of temperature and seed positioning on the substrate, four replicates of 25 seeds were used for each temperature combination $(20,25$ and $30{ }^{\circ} \mathrm{C}$ ) with seeds positioned on the germination substrate in two ways (between paper [BP] and on paper $[\mathrm{OP}])$. In the BP mode, seeds were placed between two sheets of germination paper and covered with another sheet in plastic boxes $(11 \times 11 \times 3.5 \mathrm{~cm})$. In the $\mathrm{OP}$ mode, seeds were placed on two sheets of germination paper. Papers were previously moistened with water in an amount equivalent to 2.5 times the mass of the dry paper. Plastic boxes were kept in germination chamber at constant temperature of 20,25 and $30^{\circ} \mathrm{C}$ and white light. Evaluations consisted of the identification of normal, abnormal and non-germinated seeds, according to Brazil (2009). Evaluations were performed every three days to determine the speed germination index (SGI), taking into account normal seedlings. At 20 days, normal seedling data were obtained for the first count (FC) and at 42 days for the final count $(\mathrm{G})$. FC and $\mathrm{G}$ results were expressed 
as percentage of normal seedlings.

Criteria for seedling evaluation were according to the Rules for Seed Analysis (BRASIL, 2009) considering the description available for other species. As this research evaluated a native species, not domesticated and with few studies referring to seedling classification parameters, images of normal seedlings and the main abnormalities found were performed. Thus, a graphical, manual representation was elaborated to describe the essential structures of $C$. adamantium seedlings.

The experiment was carried out in a completely randomized design in a $3 \times 2$ factorial scheme (temperatures and seed positioning on the substrate), with four replicates. The model residues were extracted and submitted to the Shapiro-Wilk normality test and Bartlett's homoscedasticity test. Then, G, FC and SGI data were submitted to analysis of variance and the means compared by the LSD test.

The temperature and substrate interaction was not significant for any of variables under study (Table 1). The simple effect of the substrate also did not influence the physiological potential expression of $C$. adamantium seeds.

Temperature showed an effect on the seed vigor expression evaluated by the FC and SGI tests. This can be explained, according to Marcos-Filho (2015), because vigor tests based on seedling performance are sensitive to detect effects of the environment on the physiological potential expression. The absence of temperature effect on the $\mathrm{G}$ test can be explained by the favorable conditions to which the test was conducted at laboratory. According to Marcos-Filho (2015), if other factors are not limiting to the germination process, this occurs under wide temperature limits.

Temperature of $25{ }^{\circ} \mathrm{C}$ was more adequate to perform FC and SGI tests (Table 2), in agreement with results observed by other authors. Dresch et al (2012) studied alternating $20-30{ }^{\circ} \mathrm{C}$ and constant temperatures of 25 and $35{ }^{\circ} \mathrm{C}$ for $C$. adamantium germination and observed differences in the germination and vigor of seeds exposed to these temperatures, also revealing superiority of constant temperature of $25^{\circ} \mathrm{C}$. The identification of the ideal germination temperature was also the aim of studies of other species of this Brazilian Biome. Brancalion et al. (2010) studied the germination of Cerrado species and concluded that the optimum germination temperature of native species is $25^{\circ} \mathrm{C}$.

These results show that, according to Marcos-Filho (2015), the optimum germination temperature depends mainly on the species and its genetic characteristics, in addition to other factors such as environmental conditions during production, management during harvest and storage and sanity of seeds.

Seed positioning on the substrate (BP or OP) did not interfere in the physiological potential expression of seeds, which can be explained because these two methods are very similar, differing only in the fact that BP presents one sheet on seeds. This sheet on seeds is used to favor the absorption of water by seeds, providing greater amount of water. However, only two sheets provided enough water to trigger the process of embryo development and formation of the normal seedling.

The germination of $C$. adamantium seeds was characterized as epigeal (Figure 1), that is, cotyledons rise above ground level (CARVALHO and NAKAGAWA, 2012). The essential structures of $C$. adamantium seedlings are: cotyledons, which in dicotyledons are two in number, and according to Brazil (2009), these species are green and foliaceous; hypocotyls, that in seedlings with epigeal germination is thin and elongated; apical bud, that is located at the shoot apex and the root system. In the case of Figure 1, the primary root was characterized as long and thin and enclosing with the tapered end, also having lateral or secondary roots.

Knowing the essential structures of a seedling is of paramount importance in assessing the physiological potential of seed lots. According to the Rules for Seed Analysis (BRASIL, 2009), in the germination test, only normal seedlings are computed.

In Figure 2, examples of normal seedlings are presented, since they present in A, B and C all essential structures well developed, complete proportional and without primary infection. The root system of seedlings is well developed and formed by long primary root and ending with thinner end. In the characterization of the root system, as previously mentioned, it was possible to identify lateral roots and, in figure $2 \mathrm{C}$, these are more visible. In addition, shoots were characterized as well developed, containing straight and elongated hypocotyl, which constitutes an important characteristic for species with epigeal germination. The shoots of normal C. adamantium seedlings were characterized with the presence of two growing green cotyledons with the respective apical bud. The species can also present multiple seed units, as shown in Figure 2C. In these situations, if at least one normal seedling is produced, it is counted as normal seedling (BRASIL, 2009).

The identification of seedling abnormalities is an essential criterion for the determination of the physiological potential, since in the expression of results, only normal seedlings are considered. Figure 3 shows the main abnormalities in $C$. adamantium seedlings. Thus, the seedling of Figure 3A shows abnormality in shoots, characterized by hypocotyl forming a spiral. In the case of seedling of figure $3 \mathrm{~B}$, the abnormality is evidenced by the absence of primary roots and secondary ones, three in number, are thin and weak. Root systems disproportionate to other seedling structures, as the seedling shown in Figure $3 \mathrm{C}$, were also criteria for classification as abnormal seedling. Regarding seedlings of figures $3 \mathrm{D}$ and $3 \mathrm{E}$, 
abnormalities were related to absent and atrophied root system, respectively. With respect to the shoot of seedlings, Figure 3E illustrates a type of abnormality defined by the absence of developed cotyledons, in addition, the seedling presents twisted hypocotyl. Other possible abnormalities in the root system are exemplified by Figures $3 \mathrm{~F}$ and $3 \mathrm{G}$. In Figure 3F, the root system remained atrophied and disproportionate in relation to the shoot of seedlings. The seedling abnormality presented in figure $3 \mathrm{G}$ was due to total deformation and atrophy of the root system, cotyledons and apical bud.
Germination and vigor tests, based on seedling performance, should be performed at constant temperature of $25{ }^{\circ} \mathrm{C}$ and seed positioning between paper and on paper may be used. The germination of Campomanesia adamantium seeds is epigeal, and the essential structures of seedlings, as well as the main abnormalities, have been described.

Table 1- Summary of variance analysis for germination test (G), germination first count (FC) and speed germination index (SGI) of Campomanesia adamantium seeds at three temperatures and two types of seed positioning in the substrate. Urutaí, 2017.

\begin{tabular}{lcccc}
\hline Sources of Variation & DF $^{*}$ & G & FC & SGI \\
\hline Temperature & 2 & 0.5626 & $<0.01$ & $<0.01$ \\
Substrate & 1 & 0.7155 & 0.2625 & 0.4766 \\
Temperature x Substrate & 2 & 0.4366 & 0.2417 & 0.4000 \\
Residue & 18 & & & \\
\hline CV (\%) & & 7.74 & 26.64 & 16.43 \\
$*$ DF = Degrees of freedom & & & &
\end{tabular}

Table 2- Germination (G), germination first count (FC) and speed germination index (SGI) of Campomanesia adamantium seeds at three temperatures and two types of seed positioning in the substrate. Urutaí, 2017.

\begin{tabular}{cccc}
\hline Treatments & G & FC & SGI \\
\hline Substrate & & & \\
Between Paper & $86.0 \mathrm{a}$ & $63.6 \mathrm{a}$ & $7.77 \mathrm{a}$ \\
On Paper & $85.0 \mathrm{a}$ & $56.6 \mathrm{a}$ & $7.40 \mathrm{a}$ \\
\hline
\end{tabular}

$\begin{array}{cccc}\text { Temperature }\left({ }^{\circ} \mathbf{C}\right) & & & \\ \mathbf{2 0} & 83.5 \mathrm{a} & 29.0 \mathrm{c} & 3.79 \mathrm{c} \\ \mathbf{2 5} & 87.0 \mathrm{a} & 84.5 \mathrm{a} & 10.72 \mathrm{a} \\ \mathbf{3 0} & 86.0 \mathrm{a} & 67.0 \mathrm{~b} & 8.25 \mathrm{~b}\end{array}$

Means followed by the same letter in the column do not differ from each other by the LSD test at $5 \%$ probability 


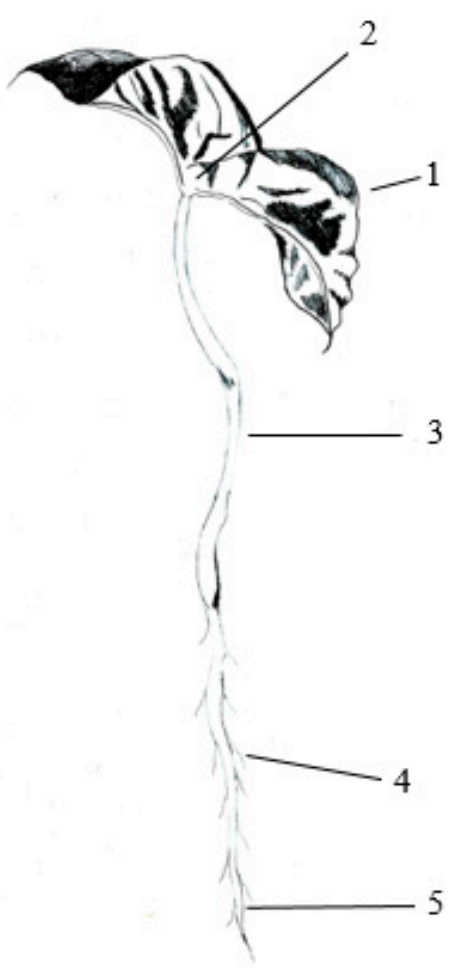

\section{1 - Cotyledons; 2 - Apical gem; 3 - Hypocotyl; 4 - Lateral root; 5 - Primary root}

Figure 1. Graphical representation of the morphological characterization of a normal seedling of Campomanesia adamantium (Dicotyledonous, epigeal germination).
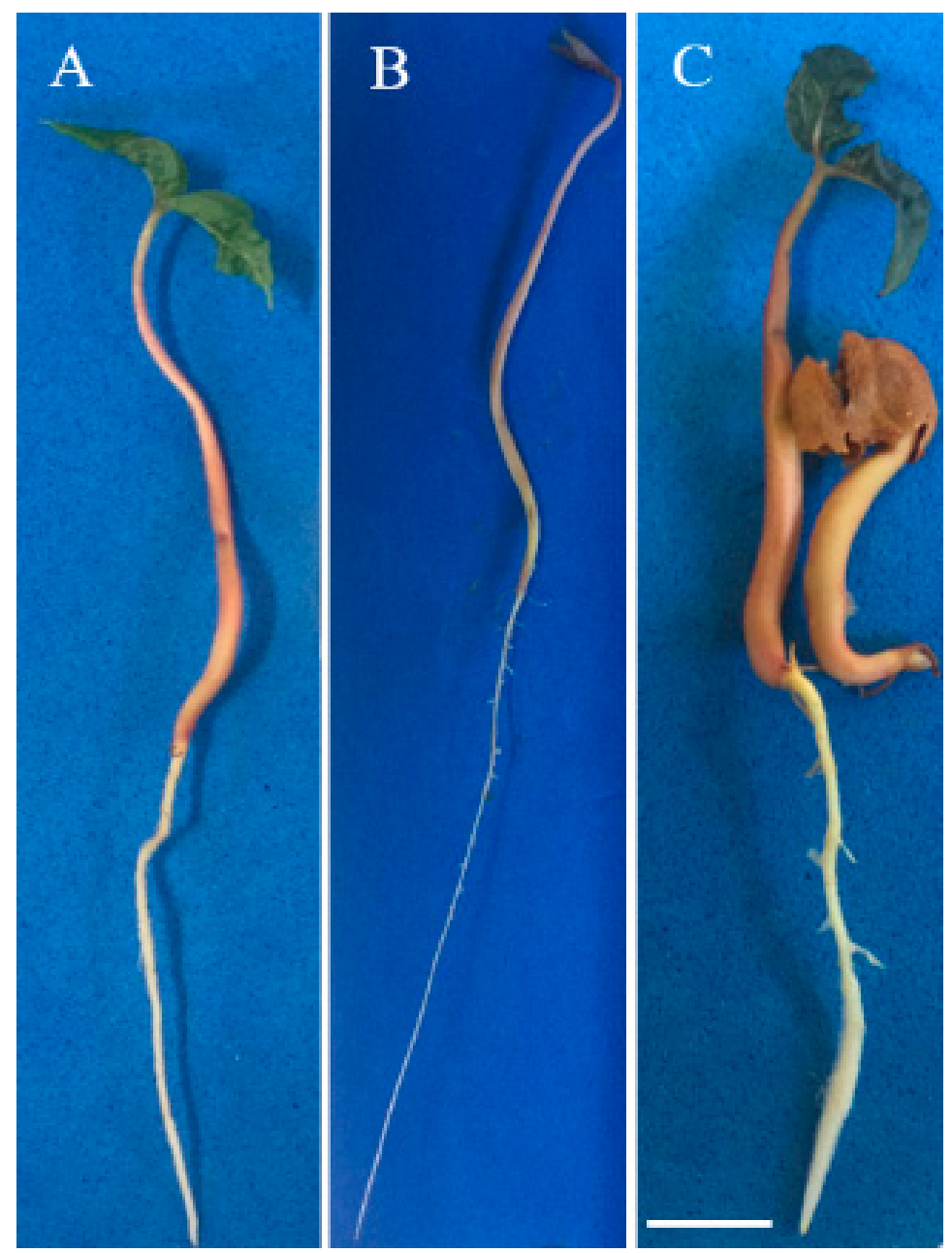

Figura 2. Normal seedlings of Campomanesia adamantium. Scale bar corresponds to $10 \mathrm{~mm}$. 

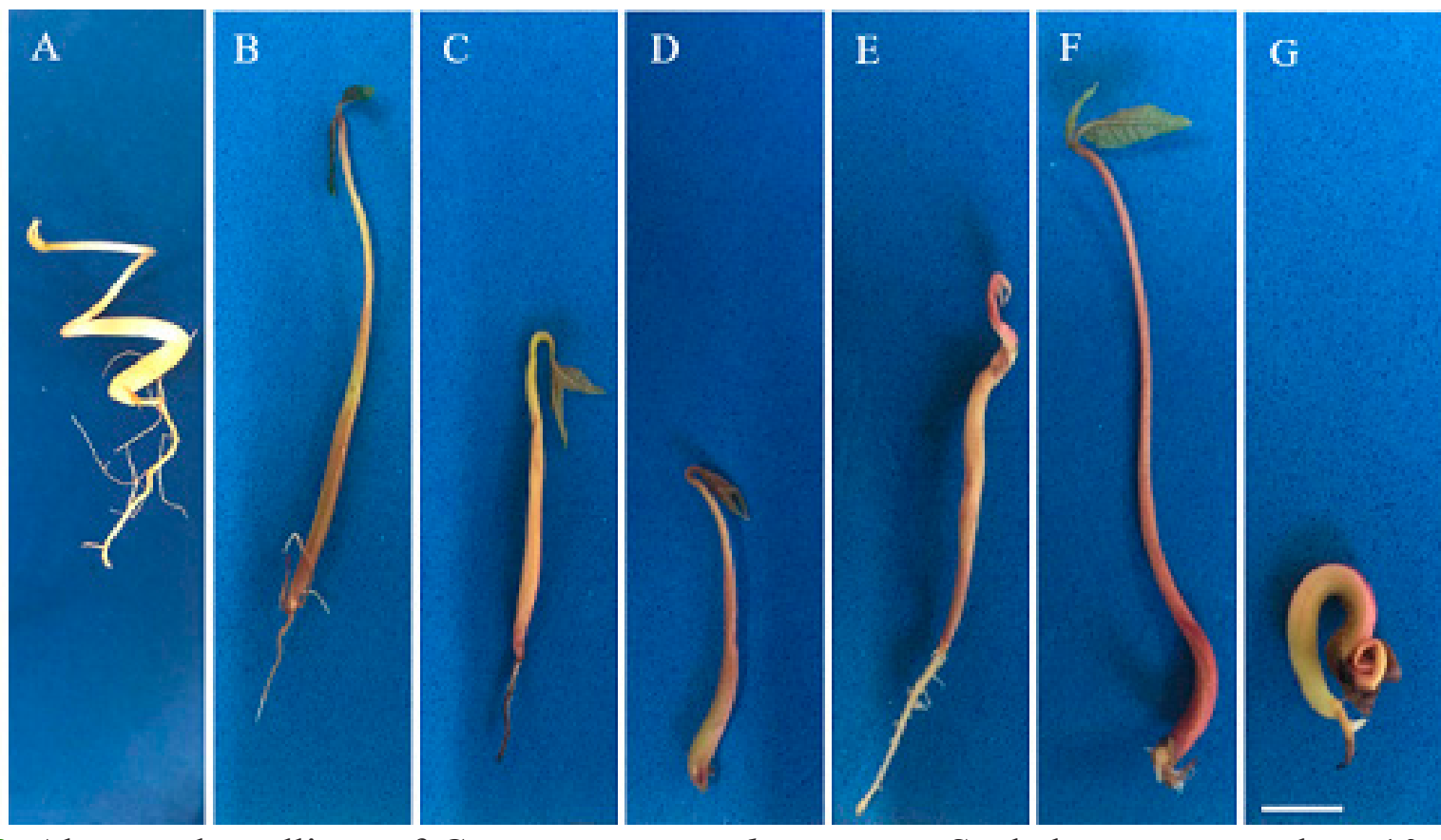

Figure 3. Abnormal seedlings of Campomanesia adamantium. Scale bar corresponds to $10 \mathrm{~mm}$.

\section{Acknowledgments}

To Helton Fernandes Leão for the manual elaboration of the Figure 1.

To IF Goiano (Instituto Federal Goiano), for the financial support.

To FAPEG (Fundação de Amparo à Pesquisa do Estado de Goiás) for granting the doctoral scholarship to the first author (Process 201610267000659; Call 03/2016).

\section{REFERENCES}

ARAÚJO, E. F. L.; SOUZA, E. R. B. Fenologia e reprodução de Campomanesia adamantium (Cambess.) O. Berg (Myrtaceae). Scientific Electronic Archives, Sinop, v.11, n.2, p.166-175, 2018.

BRANCALION, P. H. S.; NOVEMBRE, A. D. L. C.; RODRIGUES, R. R. Temperatura ótima de germinação de sementes de espécies arbóreas brasileiras. Revista Brasileira de Sementes, Brasília, v.32, n.4, p.15-21, 2010.

BRASIL. Ministério da Agricultura, Pecuária e Abastecimento, Secretaria de Defesa Agropecuária. Regras para análise de sementes. Brasília, DF, 2009. 399p.

CARVALHO, N. M.; NAKAGAWA, J. Sementes: ciência, tecnologia e produção. 5.ed. Jaboticabal: FUNEP, 2012. 590p.
COUTINHO, I. D.; COELHO, R. G.; KATAOKA, V. M. F.; HONDA, N. K.; SILVA, J. R. M.; VILEGAS, W.; CARDOSO, C. A. L. Determination of phenolic compounds and evaluation of antioxidant capacity of Campomanesia adamantium leaves. Eclética Química, São Paulo, v.33, n.4, p.53-60, 2008.

DONADIO, L. C.; MÔRO, F. V.; SERVIDONE, A. A. Frutas Brasileiras. 2 ed. Jaboticabal: FUNEP, 2004. 248 p.

DRESCH, D. M.; SCALON, S. P. Q.; MASETTO, T. E.; VIEIRA, M. C. Germinação de sementes de Campomanesia adamantium (Camb.) O. Berg em diferentes temperaturas e umidades do subtrato. Scientia Forestalis, Piracicaba, v.40, n. 94, p.223-229, 2012.

INTERNATIONAL SEED TESTING ASSOCIATION ISTA. The germination test. In: ISTA, International Rules for Seed Testing. Bassersdorf: ISTA, 2018. p.5-5 - 5-56.

LANDRuM, L. R. Campomanesia, Pimenta, Blepharocalyx, Legrandia, Acca, Myrrhinium, and Luma (Myrtaceae). New York: The New York Botanical Garden, 178 p. (Flora Neotropica. Monograph, 45). 1986.

LORENZI, H.; BACHER, L.; LACERDA, M.; SARTORI, S. Frutas brasileiras e exóticas cultivadas (de consumo in natura). São Paulo: Plantarum, 2006. 640p.

MARCOS-FILHO, J. Fisiologia de sementes de plantas cultivadas. 2 ed. Londrina: Abrates, 2015. 660p. 
NAKAGAWA, J. Testes de vigor baseados no desempenho de plântulas. In: KRZYZANOWSKI, F.C.; VIEIRA, R.D.; FRANÇA NETO, J.B. (Ed.). Vigor de sementes: conceitos e testes. Londrina: ABRATES, 1999. cap.2, p.1-24.

PESKE, S. T.; VILLELA, F. A.; MENEGHELLO, G. E. Sementes: fundamentos científicos e tecnológicos. 3. Ed. Pelotas: Ed. Universitária/UFPel, 2012. 573p.
VALLILO, M. I.; LAMARDO L. C. A.; GABERLOTTI, M. L.; OLIVEIRA, E.; MORENO, P. R. H. Chemical composition of Campomanesia adamantium (Cambessédes) O. Berg' fruits. Ciência e Tecnologia de Alimentos, Campinas, v.26, n.4, p.805-810. 2006. 